\title{
How Are Entrepreneurial Intentions Affected by Emotional Intelligence and Creativity?
}

\author{
Fatih Yıldırım¹, Inci Yılmazlı Trout ${ }^{2 *}$, Stephanie Hartzell ${ }^{3}$ \\ ${ }^{1}$ Department of Business Administration, Faculty of Business and Administrative Sciences, Erzurum Technical University, \\ ETU Yakutiye/Erzurum, Turkey \\ ${ }^{2}$ International Education and Entrepreneurship Program, Dreeben School of Education, University of the Incarnate Word, \\ 4301 Broadway, San Antonio, TX, 78209, USA \\ ${ }^{3}$ Dreeben School of Education, University of the Incarnate Word, 4301 Broadway, San Antonio, TX, 78209, USA \\ ${ }^{*}$ Corresponding author, e-mail: yilmazli@uiwtx.edu
}

Received: 01 June 2018, Accepted: 09 August 2018, Published online: 28 January 2019

\begin{abstract}
Entrepreneurship is important for developed countries to sustain their welfare levels and for developing countries to increase their level of welfare. Many entrepreneurs contribute significantly to the national economy of their countries. The purpose of our research is to determine how graduate students' entrepreneurial intentions are related to emotional intelligence and what role creativity plays in this process. This quantitative research study was conducted with graduate students at a private university in the southwest region of the USA. The data were collected from 399 participants via an online survey and analyzed by completing a Structural Equation Modelling. The results showed that entrepreneurial intentions are affected directly and positively by problem-solving skills, emotional self-awareness, and impulse control. Additionally, we found that problem-solving skills affect creativity directly and positively while creativity does not have a direct effect on entrepreneurial intentions.
\end{abstract}

Keywords

emotional intelligence, creativity, entrepreneurial intentions

\section{Introduction}

Entrepreneurship is defined as "a multi-dimensional concept that occurs in different contexts and in all types of organizations. It is about people, their choices and actions in starting, taking over or running a business, or their involvement in a company's strategic decision making" (Mortan et al., 2014: p.98). Entrepreneurship has gained importance in the past two decades particularly due to major economic expansion (Rhee and White, 2007), and has become a concept of increased significance in the environment of uncertainty that has emerged with globalization and advanced technology. Job environments and opportunities have changed with universalization, competition, and fast-growing technology that have occurred in socio-economic systems (Farahbod et al., 2013; Ozaralli and Rivenburgh, 2016). This has led individuals to become entrepreneurs and to create small businesses, as getting employed by companies became more difficult. Entrepreneurship is an important concept that affects countries' level of development, and in fact, is affected by several factors.
Although the traditional view of entrepreneurship is linked with creating new ventures, and wealth creation (Schumpeter, 1934; Low and Macmillan, 1988), this definition has been changing to include personal characteristics and behaviors of entrepreneurs during the entrepreneurial process as well as the factors influencing this process (Shane and Venkataraman, 2000). The initiation of entrepreneurship stems from the intentions of entrepreneurs. Krueger et al. (2000) state that intentions are considered as reliable predictors of the entrepreneurial process and play a mediating role in attitudes towards the action (Zampetakis et al., 2009b). Entrepreneurial process involves internal factors such as personality traits as well external factors such as social and societal factors. Internal factors include stress management, creativity, problem-solving skills, and having the ability to influence others to achieve desired goals through emotional recognition process. These traits are often exhibited by entrepreneurs. External factors include personal experiences, 
education, family, economical, and political climate (Ozaralli and Rivenburgh, 2016; Davis and Peake, 2014). As the entrepreneurial process often involves problems, obstacles, and frustrations, people who are capable of coping with these negativities and being persistent and resilient are more likely to be successful when engaged in this process (Hassan and Omar, 2016).

While there are multiple personal and social factors such as culture, education, technological environment, social environment, and family that play a role in entrepreneurial intentions, it is suggested that emotional intelligence plays an important role as well (Mortan et al., 2014). Emotional intelligence is defined as the "ability to monitor one's own and other's feelings and emotions, to discriminate among them and to use this information to guide one's thinking and actions" (Salovey and Mayer, 1990:p.189). Goleman (1995) developed an emotional intelligence model consisting of two main aspects that are; social and personal skills. Social skills include social communication and empathy while personal skills include self-motivation, self-management, and self-awareness. Goleman (1995) suggests that emotional intelligence can be improved and increased through proper training and education.

While emotional intelligence is studied widely in other fields such as job performance, leadership, and mental health (Humphrey, 2013), the focus of research has recently shifted towards entrepreneurship (Baron, 2008; Cardon et al., 2012; Zachary and Mishra, 2010) indicating that emotional intelligence is a predictor of entrepreneurial intentions and behaviors (Zampetakis et al., 2009b; Ahmetoglu et al., 2011). Individuals with high emotional intelligence are more capable of coping with stress, better able to influence people, and more creative (Rhee and White, 2007; Zampetakis et al., 2009a; Davis and Peake, 2014; Nikolau and Tsaousis, 2002).

Creativity has been considered as a component of entrepreneurship as it entails recognizing opportunities, generating ideas, and innovating (Schumpeter, 1934). In entrepreneurship, creativity refers to the generation of the novel ideas (Amabile, 1996; Ames and Runco, 2005) as "novel and useful ideas are the lifeblood of entrepreneurship" (Ward, 2004, p.174).

Developed countries regard entrepreneurship as an important tool to increase their power, while developing countries regard it as a tool to continue their development. However, entrepreneurship can only be achieved through qualified human resources. In alignment with this, the purpose of this study is to measure the level of entrepreneurial intentions of future generations and measure the effects of emotional intelligence and creativity on entrepreneurial intentions as these concepts are considered to affect entrepreneurial intentions.

\section{Methodology}

In literature, there are studies on the effects of emotional intelligence and creativity on entrepreneurship, however these concepts were researched separately. Thus, this study is significant in terms of being on the entrepreneurial intentions of graduate students as well as including both variables in one model. We present in our research model on the conceptual relationships between the dependent and independent variables in Fig. 1.

Based on the model shown in Fig. 1, we developed the following hypotheses:

$\mathrm{H}_{1}$ : As the "problem solving skills" dimension of emotional intelligence increases, creativity increases.

$\mathrm{H}_{2}$ : Entrepreneurial intentions increase as the "problem solving skills" dimension of emotional intelligence increases.

$\mathrm{H}_{3}$ : As the "interpersonal relations" dimension of emotional intelligence increases, creativity increases.

$\mathrm{H}_{4}$ : As the "interpersonal relations" dimensions emotional intelligence increases, entrepreneurial intentions increase.

$\mathrm{H}_{5}:$ As the "emotional self-awareness" dimension of emotional intelligence increases, creativity increases.

$\mathrm{H}_{6}$ : As the "emotional self-awareness" dimension of emotional intelligence increases, entrepreneurial intentions increase.

$\mathrm{H}_{7}$ : As the "impulse-control" dimension of emotional intelligence increases, creativity increases.

$\mathrm{H}_{8}$ : As the "impulse-control" dimension of emotional intelligence increases, entrepreneurial intentions increase.

$\mathrm{H}_{9}$ : As creativity increases, entrepreneurial intentions increase.

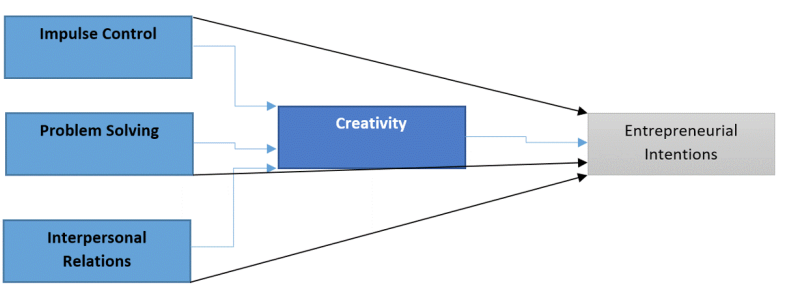

Fig. 1 The research model 


\subsection{Sampling and data collection}

This study was conducted at a private university in the U.S.A that has a diverse international student population. This university offers master's and doctoral programs in different disciplines which makes it a good fit for the purpose and the model of this research. We investigated participants from many subject areas in order to determine how emotional intelligence affects entrepreneurial intentions and the role that creativity plays in this process across genres. The graduate and professional studies students were chosen because the researchers believe that this population represents a more mature group of students who are likely to have a specific career selected. The total number of graduate level students including the Professional Studies students is 1881 . We determined our needed sample size to be 319 by using an online tool - Survey System Sample Size Calculator. Using a simple random sampling, our sample consisted of 399 students. As the instrument for this study was an online survey, surveys were distributed via email. Although 407 students took the survey, only 399 were valid and included in the study.

\subsection{Survey instrument}

In developing the survey instrument for the study, we were influenced by the instruments by Naktiyok and Timuroglu (2009); Kickul and D'Intino (2005), and Salovey and Mayer (1990). The survey consisted of 35 questions with 6 factors that are; impulse control, problem solving, interpersonal relations, emotional self-awareness, entrepreneurial intentions, and creativity. Three of the questions were related to descriptive statistics asking information about gender, program, and what year the participant is in the program. The survey instrument used a 5-point Likert scale that ranged between 1-strongly disagree and 5-strongly agree.

\subsection{Data analysis}

In order to test our hypothesis, first confirmatory and exploratory factor analyses were performed to inform on the quality of the survey factors. Then, based on correlational coefficients of dimensions that showed fit, relationships between them were determined. After this step, the proposed model was tested with structural equation modeling (SEM) to determine relationships between variables.

\section{Results}

The scale measuring the levels of emotional intelligence consisted of 20 items with 4 dimensions of emotional intelligence. This scale had a Cronbach's alpha coefficient of 0.658 . This supports that the scale provides a reliable measurement of the emotional intelligence levels.

The second part of the survey aiming to measure the levels of creativity consisted of 5 items. The Cronbach's alpha coefficient of this scale was 0.667 which indicates a reliable measurement. The scale for measuring the levels of entrepreneurial intentions consisted of 5 items and the Cronbach's alpha coefficient of the scale was 0.923 .

The results of the confirmatory factor analysis of dependent and independent variables are presented in Fig. 2 with standardized coefficients. As presented in Fig. $2,3^{\text {rd }}$ and $5^{\text {th }}$ questions from the problem-solving dimension, $6^{\text {th }}$ and $7^{\text {th }}$ questions from the emotional self-awareness dimension, and $1^{\text {st }}$ question from the impulse control dimension were removed due to their negative effect on the fit indices.

The results of the confirmatory factor analysis in relation to creativity are presented in Fig. 3. According to the results in Fig. 3, there was no reason to remove any questions.

The results of the confirmatory factor analysis in relation to entrepreneurial intentions are presented in Fig. 4. The results did not indicate removal of any questions related to entrepreneurial intentions. Although the RMSEA did not show perfect fit, it is still at an acceptable level when considered together with other fit indexes.

The fitness indices based on the confirmatory factor analysis are presented in Table 1 (Meydan and Şeşen, 2011) and Table 2. According to Table 1, all the variables in the

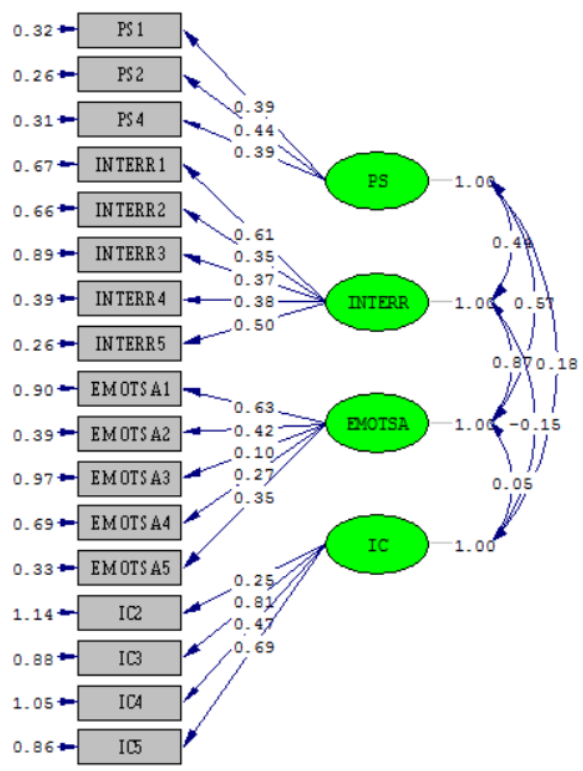

Chi-Square $=312.52, \mathrm{df}=113, \mathrm{P}-\mathrm{value}=0.00000, \mathrm{RMSEA}=0.067$

Fig. 2 Results of the confirmatory factor analysis in relation to emotional intelligence 


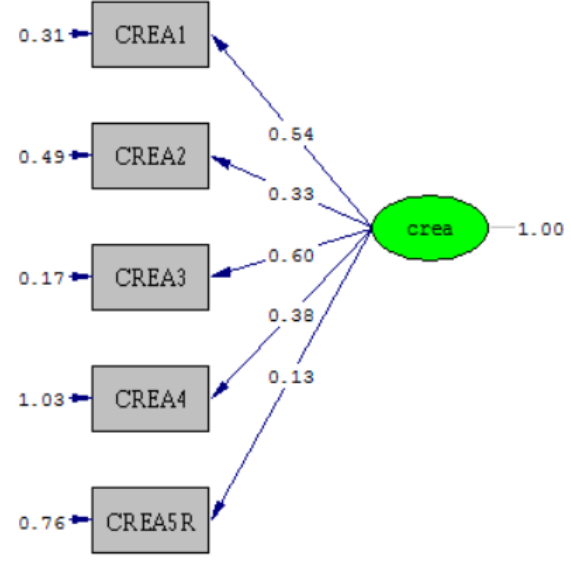

Chi-Square $=16.74, \mathrm{df}=5, \mathrm{P}-\mathrm{value}=0.00502, \mathrm{RMSEA}=0.077$

Fig. 3 Results of the confirmatory factor analysis in relation to creativity

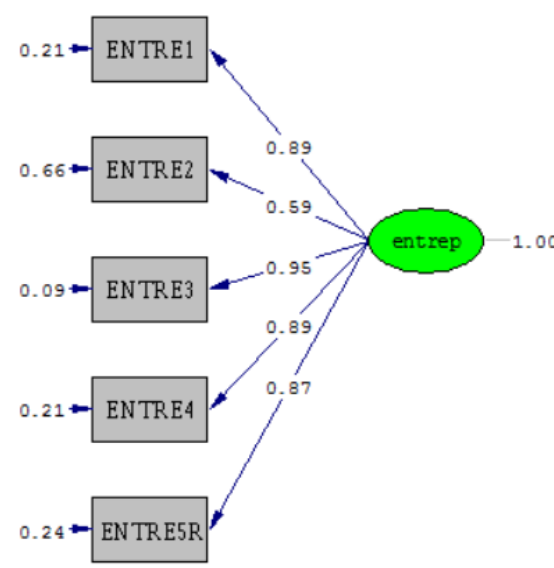

Chi-Square $=20.44, d f=5, P-v a l u e=0.00103$, RMSEA $=0.088$

Fig. 4 Results of the confirmatory factor analysis in relation to entrepreneurial intentions

study showed goodness of fit according to the confirmatory factor analysis. The statistical values and correlation coefficients of the variables are summarized in Table 3.

The results presented in Table 3 show the relationship between impulse control and emotional self-awareness is not significant. The correlation analysis showed a significant and negative relationship between impulse control and interpersonal relationships. The relationships between other dimensions were significant and meaningful. The relationship between problem solving dimension and interpersonal relationships, emotional self-awareness, impulse control, creativity, and entrepreneurial intentions was significant and positive. Creativity has a significant relationship with entrepreneurial intentions and all the dimensions of emotional intelligence.
Table 1 Goodness of fit indices

\begin{tabular}{|c|c|c|c|c|c|c|c|c|}
\hline \multirow[b]{2}{*}{ Variable } & \multicolumn{8}{|c|}{ Values } \\
\hline & $\chi^{2}$ & $(s d)$ & $\chi^{2} / s d$ & CFI & NFI & NNFI & AGFI & RMSEA \\
\hline EI & 312.52 & 113 & 2.76 & 0.96 & 0.94 & 0.92 & 0.95 & 0.067 \\
\hline Creativity & 16.74 & 5 & 3.34 & 0.96 & 0.94 & 0.92 & 0.95 & 0.077 \\
\hline Ent. Int. & 20.44 & 5 & 4.08 & 0.99 & 0.99 & 0.99 & 0.94 & 0.088 \\
\hline \multicolumn{2}{|c|}{$\begin{array}{l}\text { Goodness of } \\
\text { Fit Unit }\end{array}$} & \multicolumn{4}{|c|}{$\begin{array}{l}\text { Good Fitness } \\
\text { Values }\end{array}$} & \multicolumn{3}{|c|}{$\begin{array}{c}\text { Acceptable Fitness } \\
\text { Values }\end{array}$} \\
\hline \multicolumn{2}{|l|}{$\chi^{2} / d f$} & \multicolumn{4}{|c|}{$\chi^{2} / d f \leq 2$} & \multicolumn{3}{|c|}{$\chi^{2} / d f \leq 5$} \\
\hline \multicolumn{2}{|l|}{ RMSEA } & \multicolumn{4}{|c|}{$0.00 \leq \mathrm{RMSEA} \leq 0.05$} & \multicolumn{3}{|c|}{$0.05 \leq \mathrm{RMSEA} \leq 0.10$} \\
\hline \multicolumn{2}{|l|}{ AGFI } & \multicolumn{4}{|c|}{$0.90 \leq \mathrm{AGFI} \leq 1.00$} & \multicolumn{3}{|c|}{$0.80 \leq \mathrm{A} \mathrm{GFI} \leq 0.90$} \\
\hline \multicolumn{2}{|l|}{ CFI } & \multicolumn{4}{|c|}{$0.95 \leq \mathrm{CFI} \leq 1.00$} & \multicolumn{3}{|c|}{$0.90 \leq \mathrm{CFI} \leq 0.95$} \\
\hline \multicolumn{2}{|c|}{ NFI and NNFI } & \multicolumn{4}{|c|}{$0.95 \leq \mathrm{NFI} \leq 1.00$} & \multicolumn{3}{|c|}{$0.90 \leq \mathrm{NFI} \leq 0.95$} \\
\hline
\end{tabular}

Entrepreneurial intentions have significant relationships with all the variables except for emotional self-awareness.

After the structural characteristics of the variables in the research model were confirmed, a path analysis was used to test whether the model and the hypotheses were confirmed as a whole. The results of the path analysis showing the goodness of fit values and regression coefficients are summarized in Fig. 5.

Fig. 5 shows the beta coefficients of the variables while Table 4 shows the goodness of fit values of the model. The significance levels ( $p$ value) of the coefficient for variables with significant beta values are shown in parenthesis. The fitness values show that the presented research model shows an acceptable fit. We found that problem solving increases creativity significantly $(\beta=0.91, p<0.10)$. Also, impulse control increases entrepreneurship directly $(\beta=0.15, p<0.10)$.

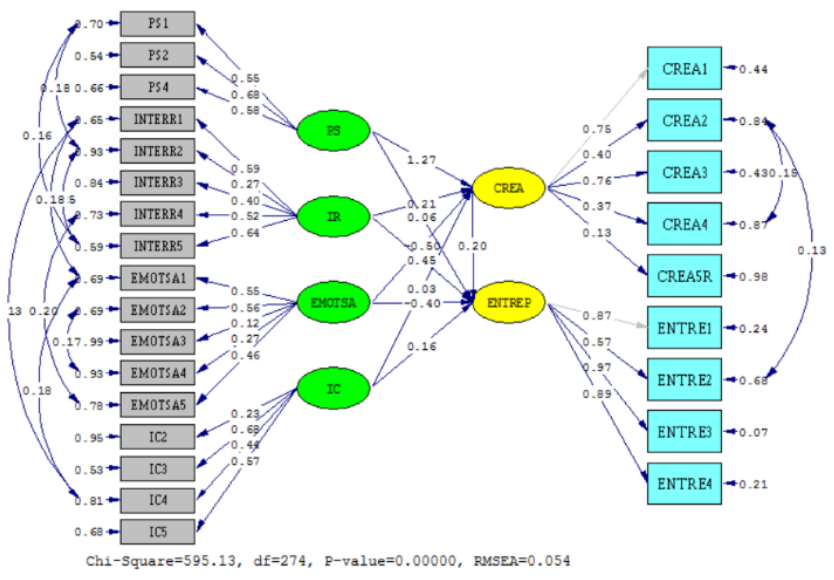

Fig. 5 Non-standardized values of the model. Abbreviations: PS: Problem solving, INTERR: interrelationships, EMOTSA: emotional self-awareness, IC: impulse control, CREA: creativity, ENTREP: entrepreneurial intentions. 
Table 3 Descriptive statistics and correlation coefficients of the variables

\begin{tabular}{|c|c|c|c|c|c|c|c|c|}
\hline Variable & Mean. & St.D. & 1 & 2 & 3 & 4 & 5 & 6 \\
\hline 1-Problem Solving & 4.28 & 0.42 & 1 & & & & & \\
\hline 2-Interrelations & 3.99 & 0.55 & $0.300 * *$ & 1 & & & & \\
\hline 3-Emotional S. Awar. & 3.96 & 0.50 & $0.353 * *$ & $0.483^{* *}$ & 1 & & & \\
\hline 4-Impulse Control & 2.81 & 0.69 & $0.134 * *$ & $-0.110 *$ & -0.20 & 1 & & \\
\hline 5- Creativity & 3.77 & 0.52 & $0.530 * *$ & $0.201 * *$ & $0.279 * *$ & $0.222 * *$ & 1 & \\
\hline 6-Entrep. Inten. & 3.34 & 1.09 & $0.160 * *$ & $0.120 *$ & 0.007 & $0.130 * *$ & $0.228 * *$ & 1 \\
\hline
\end{tabular}

Table 4 Goodness of fit indices of path analysis

\begin{tabular}{lc}
\hline RMSEA & 0.054 \\
\hline$\chi^{2}$ & 2.17 \\
$\chi^{2} / s d$ & 1.55 \\
CFI & 0.93 \\
AGFI & 0.87 \\
NFI & 0.88 \\
NNFI & 0.91 \\
\hline$p=0.000$ &
\end{tabular}

When the path coefficients are evaluated, the dimensions of INTERR, EMOTSA, and IC did not affect creativity significantly. PS, INTERR, EMOTSA, and CREA did not affect entrepreneurial intentions significantly. Therefore, no mediator affect was found. Only PS and CREA, and IC and ENTREP relationships showed significant relations according to the $t$ values. Therefore, an alternative SEM model was proposed, and the t-values are presented in Fig. 6.

The effect of creativity on entrepreneurial intentions was removed from the model presented in Fig. 6. The fitness values of the model show that the alternative model is acceptable. PS affects creativity and entrepreneurial intentions directly. EM and IC also affect entrepreneurial intentions directly.

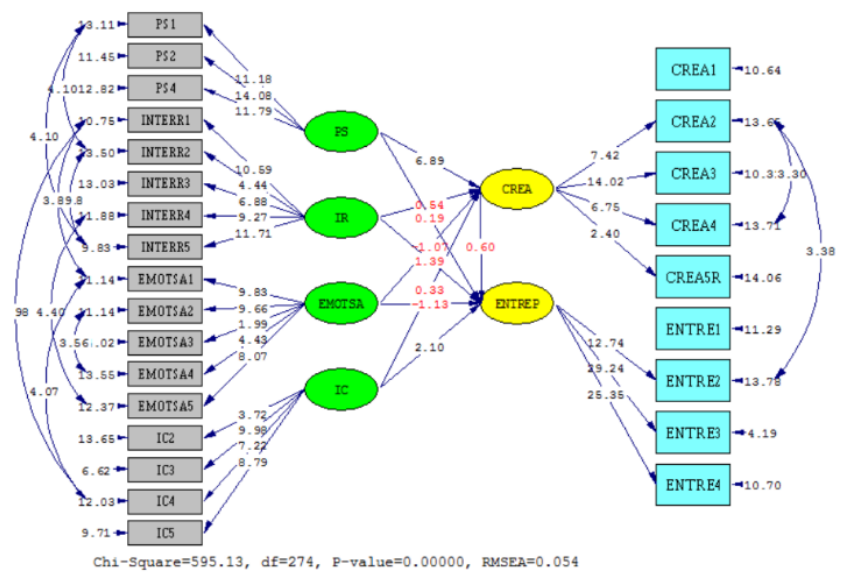

Fig. 6 t-values of the model
The effect of creativity on entrepreneurial intentions was removed from the model in Fig. 7. The fitness values of the model showed that the alternative model is acceptable. Problem solving affects creativity and entrepreneurial intentions directly. EM and IC also affect entrepreneurial intentions directly.

The hypothesis results with direct effects based on the findings are summarized in Table 5.

\section{Discussion and Conclusion}

In this study, a structural equation model was used to test 9 hypotheses where four were supported while five were refuted. The participants consisted of 147 female and 252 male graduate students with a total of 399. The mean of the responses for creativity questions was 3.34 which indicates that students were relatively indecisive about their creativity. Students being at a young age and getting to know themselves about creativity support their indecisiveness. However, the mean was 3.77 for questions related to entrepreneurial intentions which indicates they are slightly more decisive on their entrepreneurial intentions. The responses show that students scored high on problem solving skills, interpersonal relationship skills, and emotional self-awareness while they scored low on impulse control.

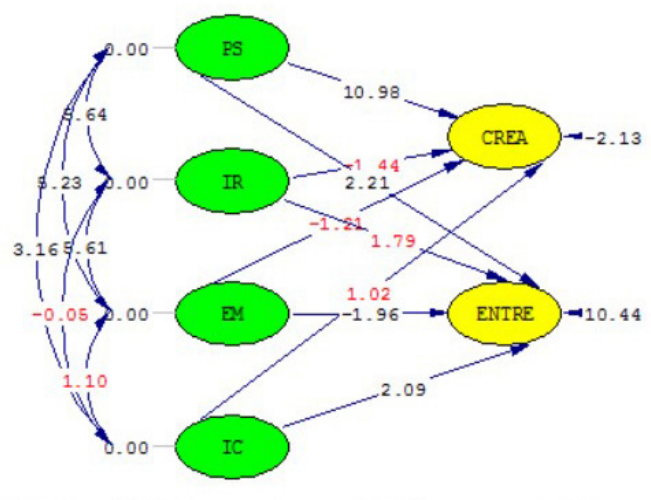

Chi-Square $=475.53, \mathrm{df}=195, \mathrm{P}-\mathrm{value}=0.00000, \mathrm{RMSEA}=0.060$

Fig. $7 \mathrm{t}$-values of the alternative model. $\mathrm{RMSEA}=0.60, \chi^{2}=475.53$, $\chi^{2} / s d=2.43, \mathrm{NFI}=0.89, \mathrm{NNFI}=0.91, \mathrm{AGFI}=0.88, \mathrm{CFI}=0.94, p=0.000$ 
Table 5 Hypothesis test results

\begin{tabular}{lcc}
\hline Path & Hypothesis & Result \\
\hline PS $\rightarrow$ CREA & $\mathrm{H}_{1}$ & Supported \\
PS $\rightarrow$ ENTREP & $\mathrm{H}_{2}$ & Supported \\
INTERR $\rightarrow$ CREA & $\mathrm{H}_{3}$ & Refuted \\
INTERR $\rightarrow$ ENTREP & $\mathrm{H}_{4}$ & Refuted \\
EMOTSA $\rightarrow$ CREA & $\mathrm{H}_{5}$ & Refuted \\
EMOTSA $\rightarrow$ ENTREP & $\mathbf{H}_{6}$ & Supported \\
IC $\rightarrow$ CREA & $\mathrm{H}_{7}$ & Refuted \\
IC $\rightarrow$ ENTREP & $\mathbf{H}_{8}$ & Supported \\
CREA $\rightarrow$ ENTREP & $\mathrm{H}_{9}$ & Refuted \\
\hline
\end{tabular}

- $\chi^{2}$ value is significant, however, when considered with other indicators the model can be accepted.

In the structural equation model, we found that a significant positive relationship between the dimension of problem-solving skills and both creativity and entrepreneurial intentions. Therefore, $\mathrm{H}_{1}$ and $\mathrm{H}_{2}$ were supported. This indicates that as the level of problem-solving skills increases, the students' creativity levels and entrepreneurial intentions increase. This is an expected result as individuals overcome problems, their self-confidence increases which increases creativity. Additionally, the confidence gained by problem solving increases future entrepreneurial intentions.

The level of interpersonal relationships in students does not affect the level of creativity and entrepreneurial intentions significantly. Therefore, $\mathrm{H}_{3}$ and $\mathrm{H}_{4}$ were refuted. As the level of interpersonal relationships increase, the levels of creativity and entrepreneurial intentions do not increase significantly.

Another variable that was tested in the alternative structural equation model is emotional self-awareness. The dimension of emotional self-awareness was found to affect entrepreneurial intentions significantly and positively. However, emotional self-awareness did not have any significant effects on the level of creativity. Therefore, $\mathrm{H}_{5}$ was refuted while $\mathrm{H}_{6}$ was supported. As the students' level of emotional awareness increases, their entrepreneurial intentions increase.

The results showed that impulse control does not affect creativity significantly. However, as the level of impulse control increases, entrepreneurial intentions increase. Thus, $\mathrm{H}_{7}$ was refuted while $\mathrm{H}_{8}$ was supported.

One surprising relationship that was not demonstrated to be significant was that between creativity and entrepreneurial intentions. Therefore, $\mathrm{H}_{9}$ was refuted. The reason for this surprising finding is considered to be related to the responses given to the creativity questions in the survey indicating they are indecisive about creativity.

Although the proposed model was not fully supported, the amended model does offer some interesting results that can assist in the development of entrepreneurial intentions. These results can be helpful in two ways. First, this analysis describes the current state of graduate students and their characteristics that related to entrepreneurial intentions and creativity. Secondly, this data can be used in conjunction with emotional intelligence theory (Goleman, 1995) to demonstrate that if these students really want to become entrepreneurs, they may be deficient in some areas, such as interpersonal relations. These deficiencies can be addressed before the students embark on their potential entrepreneur futures.

Based on the result of creativity not affecting emotional intelligence directly, it is not sufficient to provide education towards improving creativity of students with the purpose of increasing students' entrepreneurial intentions. Thus, educators should also implement educational programs to increase emotional intelligence along with creativity. This approach would then allow students to get a better understanding of how they can turn their creativity into innovation or a commercial product.

\subsection{Research limitations}

One of the limitations is that only a quantitative approach was adopted in this study. As emotional intelligence and creativity are concepts based on interaction, adopting a qualitative approach to further research would be beneficial. We recommend a mixed method approach for future research.

Another limitation of the study is that it was conducted with students from only one university. We recommend including students from multiple different schools in order to understand the difference between schools.

This is a cross-sectional study in which the data is limited. Therefore, the data is not suitable for drawing causational conclusions. In order to create a cause-effect relationship between the variables used in this study, a longitudinal design is required. It would be beneficial to determine whether students are involved in entrepreneurial ventures after they graduate. 


\section{References}

Ahmetoglu, G., Leutner, F., Chamorro-Premuzic, T. (2011) "EQ-nomics: Understanding the relationship between individual differences in Trait Emotional Intelligence and entrepreneurship", Personality and Individual Differences, 51(8), pp. 1028-1033. https://doi.org/10.1016/j.paid.2011.08.016

Amabile, T. M. (1996) "Creativity and Innovation in Organizations", Harvard Business School Background Note, pp. 239-396.

Ames, M., Runco, M. A. (2005) "Predicting Entrepreneurship From Ideation and Divergent Thinking", Creativity and Innovation Management, 14(3), pp. 311-315.

https://doi.org/10.1111/j.1467-8691.2004.00349.x

Baron, R. A. (2008) "The Role of Affect in the Entrepreneurial Process", Academy of Management Review, 33(2), pp. 328-340. https://doi.org/10.5465/amr.2008.31193166

Cardon, M. S., Foo, M.-D., Shepherd, D., Wiklund, J. (2012) "Exploring the heart: Entrepreneurial emotion is a hot topic", Entrepreneurship Theory and Practice, 36(1), pp. 1-10. https://doi.org/10.1111/j.1540-6520.2011.00501.x

Davis, P. E., Peake, W. O. (2014) "The Influence of Political Skill and Emotional Intelligence on Student Entrepreneurial Intentions: An Empirical Analysis", Small Business Institute Journal, 10(2), pp. 19-34.

Farahbod, F., Azadehdel, M., Modifi, M. K., Shahabi, S., Khoshamooz, H., Pazhouh, L. D., Ghorbaninejad, N., Farzaneh, S. (2013) "The relationship between trait emotional intelligence and entrepreneurship attitudes and intentions", Journal of Public Administration and Policy Research, 5(3), pp. 79-85. https://doi.org/10.5897/JPAPR2013.0242

Goleman, D. (1995) "Emotional intelligence", Bantam Books, New York, USA.

Hassan, R. A., Omar, S. N. B. (2016) "The effect of emotional intelligence and entrepreneurial attitude on entrepreneurial intention", Kuwait Chapter of Arabian Journal of Business and Management Review, 5(12), pp. 1-10.

Humphrey, N. (ed.) (2013) "Social and Emotional Learning: A Critical Appraisal", 1st ed., SAGE Publications Ltd., London, UK.

Kickul, J., D’Intino, R. S. (2005) "Measure for Measure: Modeling Entrepreneurial Self-Efficacy onto Instrumental Tasks Within the New Venture Creation Process", New England Journal of Entrepreneurship, 8(2), Article 6. [online] Available at: https://digitalcommons.sacredheart.edu/neje/vol8/iss2/6 [Accessed: 12 June 2018]

Krueger, N. F., Reilly, M. D., Carsrud, A. L. (2000) "Competing models of entrepreneurial intention", Journal of Business Venturing, 15(5-6), pp. 411-432. https://doi.org/10.1016/S0883-9026(98)00033-0

Low, M. B., MacMillan, I. A. (1988) "Entrepreneurship: Past Research and Future Challenges", Journal of Management, 14(2), pp. 139-161. https://doi.org/10.1177/014920638801400202

Meydan, C. H., Şeşen H. (2011) "Yapısal Eşitlik Modellemesi: AMOS Uygulamaları" (Structural Equation Modelling: AMOS applications), Detay Yayıncılık, Ankara, Turkey. (in Turkish)
Mortan, R. A., Ripoll, P., Carvalho, C., Bernal, M. C. (2014) "Effects of emotional intelligence on entrepreneurial intention and self-efficacy", Journal of Work and Organizational Psychology, 30(3), pp. 97-104.

https://doi.org/10.1016/j.rpto.2014.11.004

Naktiyok, A., Timuroglu, M. K. (2009) "Ogrencilerin motivasyonel degerlerinin girisimcilik niyetleri uzerine etkisi ve bir uygulama" (The effects of student motivational levels on their entrepreneurial intentions), Ataturk Universitesi Iktisadi ve Idari Bilimler Dergisi, 23(3), pp. 85-103. (in Turkish)

Nikolau, I., Tsaousis, I. (2002) "Emotional intelligence in the workplace: Exploring its effects on occupational stress and organizational commitment", The International Journal of Organizational Analysis, 10(4), pp. 327-342.

https://doi.org/10.1108/eb028956

Ozaralli, N., Rivenburgh, N. K. (2016) "Entrepreneurial intention: antecedents to entrepreneurial behavior in the U.S.A and Turkey", Journal of Global Entrepreneurship Research, 6(3), pp. 1-32. https://doi.org/10.1186/s40497-016-0047-x

Rhee, K. S., White, R. J. (2007) "The Emotional Intelligence of Entrepreneurs", Journal of Small Business \& Entrepreneurship, 20(4), pp. 409-425. https://doi.org/10.1080/08276331.2007.10593408

Salovey, P., Mayer, J. D. (1990) "Emotional Intelligence", Imagination, Cognition and Personality, 9(3), pp. 185-211. https://doi.org/10.2190/DUGG-P24E-52WK-6CDG

Schumpeter, J. A. (1934) "The Theory of Economic Development", Harvard University Press, Cambridge, MA, USA.

Shane, S., Venkataraman, S. (2000) "The Promise of Entrepreneurship as a Field of Research", Academy of Management Review, 25(1), pp. 217-226.

https://doi.org/10.5465/amr.2000.2791611

Ward, T. B. (2004) "Cognition, creativity, and entrepreneurship", Journal of Business Venturing, 19(2), pp. 173-188. https://doi.org/10.1016/S0883-9026(03)00005-3

Zachary, R. K., Mishra, C. S. (2010) "Entrepreneurship Research Today and Beyond: Hidden in Plain Sight!", Journal of Small Business Management, 48(4), pp. 471-474. https://doi.org/10.1111/j.1540-627X.2010.00304.x

Zampetakis, L. A., Beldekos, P., Moustakis, V. S. (2009a) "Day-today entrepreneurship within organizations: The role of the trait Emotional Intelligence and Perceived Organizational Support", European Management Journal, 27(3), pp. 165-175. https://doi.org/10.1016/j.emj.2008.08.003

Zampetakis, L. A., Kafetsios, K., Bouranta, N., Dewett, T., Moustakis, V. S. (2009b) "On the relationship between emotional intelligence and entrepreneurial attitudes and intentions", International Journal of Entrepreneurial Behaviour \& Research, 15(6), pp. 595-618. https://doi.org/10.1108/13552550910995452 